\title{
Phraseological Units in Horror Comics: Comparative Study of the Translation into English, French and Spanish from a Multimodal Corpus
}

\author{
María del Carmen Baena Lupiáñez \\ Universidad de Málaga \\ Av. de Cervantes, 2, 29016, Málaga, Spain \\ mariadelcarmenbaenalupianez@gmail.com
}

\begin{abstract}
The main objective of this study is to determine the real relationship between text and image in a comic. We will know the influence of the image and the market of the horror comics in the phraseological units and their translation. Therefore, we are going to study the paralinguistic elements of horror comics. We will create a multimodal corpus in English, French and Spanish to classify the linguistic and the paralinguistic elements of comics from a more graphic and technical point of view. We also propose to carry out a comparative study of the techniques of translation of comics, considering the elements that share and differentiate these comics. Computer tools of constitution and analysis of corpora will allow us to establish several classifications related to paralinguistic and linguistic elements, including phraseological units. In this way, the translator would find a more informative classification and would document and establish correlations between texts more easily.
\end{abstract}

Keywords: Comics, Paralinguistic Elements, Phraseological Units.

\section{Introduction}

It was in the $20^{\text {th }}$ century when comics began to be published. These comics showed the canons that were established by the society at that moment: a virile, strong and courageous hero, a fragile and delicate woman, an innocent child and a truly wicked villain, among others.

Subsequently, comics evolved from a purely caricatured genre to much more varied themes. The use of its graphic and formal elements has also evolved. Today there are comics that are like true philosophical essays, or comics that are only iconic elements.

This kind of comics shows the importance that the image acquires in drawing.

This leads us to believe that text and image are two elements that cannot be separated because of their complementarities and interdependences.

In the field of translation, the translator must take into account these complementarities so that the target text has coherence, and the reader of the target language can follow the story without difficulty. The translator should also know the context in 
which the comic takes place, the psychology, the purpose of each character, their gestures, their register and the paralinguistic elements of the image. This relation between image and text not only affects the use of phraseological units, but they also include cultural connotations that may be represented in the image. That makes more difficult the translation into the target language and culture. Thus, the phraseological units, and by extension, the complete text, have to be translated taking into account the intrinsic cultural connotation of the phraseological unit and its graphic representation within the vignette, thus avoiding inconsistencies between phraseological unit and image. Consequently, the translation of comics has a greater complexity that we could imagine, due to the multitude of heterogeneous elements to be taken into account during the translation process.

It is in this context that we consider that the translation of comics is a type of specialized translation. It has its own communication codes insofar as the textual and paratextual elements are to be taken into consideration in the translation.

Thus, the translator must not only read the text, but also interpret the image that accompanies the text. He or she has to use the appropriate translation techniques according to the message conveyed, adapting the phraseological units and the image to the target culture if necessary.

\section{Translation of comics}

Despite all that has been explained and the importance of a good interpretation of paralinguistic elements, the Translation studies have not often addressed this subject in a direct and detailed way.

Thus, there are studies that focus on the analysis of comics $[8,9]$, on the specific characteristics of this genre [10] and on its semiotic aspects [2]. There are also studies that highlight the importance of the image in the translation of comics [12, 21]. We can also find some studies that analyse the gestures and facial expressions on human being in comics [11], but they do not establish a direct relationship between these elements and the translation. Authors such as Zanettin studied both linguistic corpus and comics, which indicates that it is possible to establish a relationship between corpora and comics. This aspect emphasises the complexity that exists to include the translation of comics into a single discipline insofar as comics combine image and text. The above-mentioned areas of translation share these characteristics.

Traditionally, Translation studies have considered the texts with images through the concept of "subordinate translation" [14]. However, with the evolution of comics, this concept is obsolete and corresponds no longer to the graphic representation of the current comics. Today, the concept of "paratranslation" is the most adapted to the translation of comics. We will explain this concept later.

\section{Translation, comic and image}

As Yuste Frías says [20], the image and all the elements that appear in it are not universal. It may have a different meaning from one language to another, from one 
culture to another. For instance, the colour of the image is perceived in a different way according to the language, the culture, the context and the place of the communicative context of the document of departure and that of arrival. Perception is never a simple vision, because a perception involves knowledge, memory, imagination and the cultural environment of both the text to be translated and the story that translates. He points out that colour is a cultural phenomenon that every society, every civilisation, every life, defines and "translate" in a different way according to the spatialtemporal context.

According to Yuste Frías [20], it is necessary to stop the old opposition between the text and the image in translation, in order to stop believing that the translator should only deal with the text. He says that "the new iconotextual entity formed by the text-image pair is a mixed entity where the verbal element is $100 \%$ present in the comic and the visual element is $100 \%$ present as well" [20]. So, the translator never works on a textual or iconic percentage less than $100 \%$.

As Yuste Frías notices, the author of the term "paratranslation" [20], it is a question of analysing all the elements that accompany the source text to create a target text more appropriate to the reader of the target culture, so that we can avoid misunderstandings or translation mistakes.

\section{$4 \quad$ Adaptation of comics}

Zanettin [21] establishes a typology of strategies of visual adaptation in comics (that concerns visual codes, that is, nonverbal), which goes from the publication format to the appearance of the characters and typology (change in the format of publication, in colours, in the images, in the layout; replacing, deleting or adding of pages; resizing, deleting, replacing or adding of bullets, and change of font in the labels).

Zanettin [21] also explains briefly a trendy in the translation and edition of comics: the strategy of foreignization, which means, the prevalence of the non-adaptation.

In conclusion, Zanettin [21] states that this technical translation process is carried out for cultural and commercial reasons, since comics have to be adapted in many occasions to the culture and the target language. A large number of copies can be sold in the countries where it is to be published and bring some benefits to the publishers. The culture and the characteristics of the market play a fundamental role in the components of the comics and in their translation.

\section{Relationship between textual corpora and translation of comics}

Zanettin [22], the same author who studies the visual adaptation in comics, also studies the textual corpus. Thus, there are authors who consider these two disciplines as specific and complementary to each other, although they are completely different.

Zanettin [22] considers that the textual corpora are very useful for the translator, and that its use is essential to get a good result. According to this author, textual cor- 
pora are easy to do, they allow obtaining complete information about the text, and they allow analysing the terminology and the specialized phraseology of the subject.

This could be related to what Corpas Pastor calls "translation technologies" [4]. These are the systems integrated into a translator work environment. These elements interact with each other or are used sequentially and in chain. Corpas Pastor [4] argues that the translator should use, at least, tools such as a translation memory system and an associated terminology programme.

As for the discipline that would involve this study, the Corpus Linguistics, Stéphane Patin [18] points out that it is the area that studies the speech through a digital and structured corpus. In this way, empirical textual corpus that treats the same subject is used and is organised in a way that can be analyzed and interpreted in a structured way.

\section{Phraseological units and translation of comics}

According to Corpas Pastor [3], phraseological units are lexical units are formed by lexical units that have at least two words and a compound sentence at the most. They are characterized by frequent use, by the co-existence of its component parts; by its institutionalisation; by its idiomaticity and by the degree to which all these aspects appear in the relevant phraseological unit.

Thus, Paula Romero Ganuza [7], following the German model, divides the phraseological units as follows:

\section{- Phraseology shorter than a sentence:}

- Phraseolexems: They are totally or partially idiomatic, can be modified and are verbal, nominal, adjectival and adverbial units that show different functions.

- Collocations: They are constituted by two non-idiomatic components. They are composed by two elements: a base and a placement. The base is an autosemantic word and determines the second element.

- Constructions with supporting verbs: These are non-idiomatic phraseological units that can be considered as a subgroup of the collocation. They are verbal complexes whose structure is verb + preposition + noun, and also as the structure "verb + noun". In these structures the meaning of the verb is blurred or weakened, residing the semantic nucleus of the construction in the noun.

- Routine forms: They may be totally idiomatic, partially idiomatic or may not be idiomatic.

- Proverbs or sayings: They are micro-texts that do not possess the communicative function that was attributed to the phraseolexems.

- Textual forms: They are non-idiomatic phraseological units, similar to the collocations, but at the sentence level.

However, although phraseological units have been studied a lot, these units in comics and their translation have been studied just a little. There are studies made by Russian researchers, such as those by Pavlova Alla Eduardovna [5] that focus on the 
use of phraseological units for the creation of a comic, or the study of Mercedes Ariza [1], which deals with the phraseological creativity in translation of comics. But the studies that combine phraseological units and comics are still very scarce.

\section{$7 \quad$ Objectives}

The main objective is to determine the real relation between text and image in a comic, which means, to know the degree of influence of the image and the commercial aspects of the horror comic in the phraseological units and their translation into English, French and Spanish.

Therefore, this project aims to study the paralinguistic elements of horror comics to translate their phraseological units. We are going to create a multimodal corpus in English, French and Spanish which allows to classify the linguistic (phraseological units) and the paralinguistic elements (image) of comics from a more graphic and technical point of view. In this way, the translator can find a more informative classification, can document and establish correlations between texts and images more easily.

In order to achieve this main objective, other ones will be established to complete this study.

It is also planned, thanks to the computer tools of constitution and analysis of corpus, to establish several classifications for the three languages:

- A classification of the paralinguistic elements that appear in all the comics and their function;

- A classification of phraseological units in horror comics;

- A classification of techniques of comics' translation, taking into account all the elements that have been addressed in the objectives set out above.

The project also proposes to carry out a comparative study of the techniques of translation of comics, considering the elements that share and differentiate these comics.

\section{Methodology: creation of a multimodal corpus of comics}

To achieve these objectives, the study will rely on the analysis of five horror comics:

- The Crow by James O'barr [17]: It is an American comic book published in 1989 by Caliber Press. This comic has approximately 244 pages.

- Sin City by Frank Miller [15]: It is an American graphic novel published between 1991 and 1999 by Dark Horse Comics. The comic has 7 volumes. The first and second have 208 pages; the third has 184 pages; the fourth has 240 pages; the fifth has 128 pages; the sixth has 160 pages, and the seventh has 320 pages. 
- V for Vendetta, written by Alan Moore and designed by David Lloyd [16]: It is a series of ten comics gathered later in a graphic novel. It was published between 1982 and 1988 by Vertigo Comics. V for Vendetta has 304 pages.

- The Suicide Forest, written by Juan Antonio Torres ("El Torres") and designed by Gabriel Hernández [19]: It is a comic book published between 2010 and 2011 by IDW Publishing. The comic has 104 pages.

- The Walking Dead by Robert Kirkman and Tony Moore [13]: These comic books were published in 2003 by Image Comics. It has 157 editions and 27 volumes, which have between 136 and 144 pages each one.

The interest in this kind of comics lies in the fact that the paralinguistic elements are very remarkable. Indeed, there are many symbolic elements and the characters are particularly expressive.

In addition, commercial comics and independent comics of the same genre were chosen to cover a wider field. A comic can change if it has more or less impact for commercial reasons. The format and the story change according to its impact on the market.

These comics will be established in a multimodal corpus. A multimodal corpus is defined as a corpus that links a TXT file with other files in HTML format, and whose database could record the images of the drawings [4]. Thus, systematic linguistic analyses, of a translational nature, can be carried out by means of linguistic and paralinguistic corpus textual alignment in order to appreciate the reciprocal correspondence of translation, as well as analyses more linked to the image, such as the sociocultural aspects and the adaptation. Text alignment such as AntPconc, MkAlign or Le Trameur will be used.

Once the texts have been separated from the images, the phraseological units that appear and the function they fulfil will be extracted when combined with the rest of the text and with the image. We will use the table that Corpas Pastor [3] proposes to classify the phraseological units to analyse the most frequent phraseological units in horror comics and their function in them.

\section{Results}

For the first results, we have analyzed some parts of the Spanish, the French and the English versions of "The Suicide Forest" by El Torres, and "The Crow" by James O'barr. Both are comics written originally in English. A chart illustrating these first results is shown below. They all use a colloquial register, even vulgar or slang in the case of "The Crow", and the passages that have been chosen were not violent, but when the main character and other characters talked to each other and not other actions happened. So the use of swear words or insults was much reduced.

"The Crow" is a black and white comic, which symbolises the violence of the story and the loneliness and sadness that feels the main character, while "The Suicide Forest" is a colourful comic. They use dark green to represent the forest and the dangers inside it, different kinds of blue and grey to express the loneliness of the characters and red in the violent passages. As it can be seen, they are two different comic 
books that exemplify the same notions in different ways. These specific characteristics of both comics are represented in different ways in the translation into French and Spanish and in the original English version.

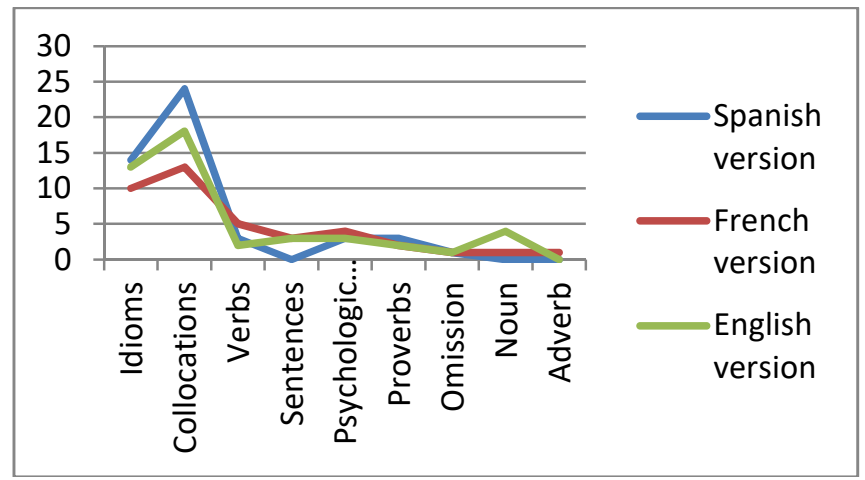

Fig. 1: First results of the study

As can be seen, the first results indicate a large use of idioms and collocations, and some uses of verbs, sentences, psychological formulae, proverbs, omissions, nouns and adverbs. The French version is the one that uses the shortest sentences, while the Spanish version uses the longest sentences. In the French version there is a trendy in using other forms instead of the phraseological units so that their sentences are shorter. However, in the Spanish version the use of phraseological units is larger, so their sentences are longer. The original English version uses very often some phraseological units, but it also replaces them by phrasal verbs or shorter units.

In the case of the collocations, it can be observed that in the three versions of both comics the formulas of "verb + noun" and "verb + preposition + noun" are the ones that repeat the most. With regard to the idioms, the verbal, adjectival and nominal idioms have been mostly found. The omissions are produced in different parts of the story, that means, the Spanish version uses the omission in a sentence that the French or the English do not, and vice versa.

In the Spanish version, it tends more to use a phraseological unit than to elaborate a complete sentence. It is the version that uses collocations (24/30) and idioms $(14 / 30)$ the most, after the English version, where appears 18/30 of collocations and $13 / 30$ of idioms. Hence no sentences, nouns or adverbs (0/14) have been found in the passages that have been analysed. In the case of the use of verbs (3/14), they have been found when in the French or English versions a phraseological unit has been used.

The French version is the only one that employs all the resources that appear in the chart. It uses more verbs (5/30) and psychological formulae (4/30) than other version. It is also the only one that uses an adverb (1/30) instead of a phraseological unit.

In the English version, the original one, more nouns can be found (4/30) than in their respective translations and the use of collocations (18/30) and idioms (13/30) is also very large. 
In short, the Spanish version is the one that uses phraseological units the most, especially collocations and idioms, so the speech is always longer than in other versions. The French version has a use more balanced of the resources so that the sentences are shorter. It is the original English version that mixes these two trends.

\section{References}

1. Ariza, Mercedes: Creatividad fraseológica y traducción en la versión española de Astérix chez les Bretons, en Ruiz Miyares, L., Alvarez Silva, M. R. (eds.). Comunicación social en el siglo XXI, Vol. I, Santiago de Cuba: Centro de Lingüística Aplicada (2011).

2. Celotti, Nadine: The Translation of Comics as a Semiotic Investigator. En el libro de Zanettin (Ed.) Comics in Translation, pp. 33-48. London: Routledge (2008).

3. Corpas Pastor, Gloria: Manual de fraseología española. Madrid, Spain: Editorial Gredos (1996).

4. Corpas Pastor, Gloria: Investigar con corpus de traducción: los retos de un nuevo paradigma. Sweden: Peter Lang (2008).

5. Eduardovna, Pavlova Alla: Phraseological units as means of creation of comic M. in the novel And. Bulgakov The Master and Margarita. Dissertation. Sciences: (2003) 10/02/01.

6. Fleury, Serge: Le Trameur <http://www.tal.univ-paris3.fr/trameur/> (2011).

7. Romero Ganuza, Paula: La delimitación de las unidades fraseológicas (UF) en la investigación alemana y española. Asociación de Jóvenes Lingüístas, pp. 905-914 (2006).

8. Groensteen, Thierry: The System of Comics. Mississipi, USA: University Press of Mississipi (2009).

9. Groensteen, Thierry: Comics and Narration. Mississipi, USA: University Press of Mississipi (2013).

10. Gubern, R. y Gasca, L. (1988): El discurso del cómic. Madrid: Cátedra (1988).

11. Gubern Garriga-Nogués, Román: De los cómics a la cinematografía. Discurso llevado a cabo para la Real Academia de Bellas Artes de San Fernando (2013).

12. Kaindl, Klaus: Thump, Whizz, Poom: A framework for the study of comics under translation. Target, Núm. 11, pp. 263-288 (1999).

13. Kirkman, R., y Moore, T.: The Walking Dead. California: Image Comics (2003).

14. Mayoral Asensio, R., Kelly, D., y Gallardo, N.: Concepto de 'traducción subordinada' (cómics, cine, canción, publicidad). Perspectivas no lingüísticas de la traducción (I). Pasado, presente y futuro de la lingüística aplicada en España. Actas del III Congreso Nacional de Lingüística Aplicada de Valencia, pp. 95-105 (1985).

15. Miller, Frank: Sin City. Milwaukie, Oregon: Dark Horse Comics (1991-1999).

16. Moore, A., y Lloyd, D.: V de Vendetta. Nueva York: Vertigo (DC Comics) (1982-1988).

17. O’Barr, James: The Crow. Northampton: Kitchen Sink Press (1993).

18. Patin, Stéphane: Apport de la textométrie dans l'analyse d'un corpus bilingue : la traduction pédagogique d'Atala par Simón Rodríguez». HISTOIRE(S) de l'Amérique Latine. Vol. 7. Art. 8 (2012).

19. Torres, J.A., y Hernández, G.: El bosque de los suicidas. San Diego, California: IDW Publishing (2010-2011).

20. Yuste Frías, José : Traduire l'image dans les albums d'Astérix. À la recherche du pouce perdu en Hispanie » dans RICHET, B. [éd.] Le tour du monde d'Astérix. Actes du colloque tenu à la Sorbonne les 30 et 31 octobre 2009, Paris : Presses Sorbonne Nouvelle, pp. 255$271(2011)$. 
21. Zanettin, Federico: Comics in Translation. London: Routledge (2008).

22. Zanettin, Federico: Corpora in translation practice. Yuste Rodrigo, Elia (Ed.) Language Resources for Translation Work and Research, LREC 2002 Workshop Proceeding. Las Palmas de Gran Canaria, pp. 10-14 (2002b).

23. Zimina, Maria et Fleury, Serge: MkAlign <http://www.tal.univ-paris3.fr/mkAlign/>. (2006). 